\title{
Editor's biographical notes
}

Professor Tran Van Hoa, a graduate from the University of Western Australia, holds higher degrees from Monash University, Victoria, Australia. He has taught widely at universities in Australia, Asia and the USA, and visited major international research institutes and universities, including Cambridge University (UK), the London School of Economics (UK), CORE at the Université Catholique de Louvain (Belgium), Stanford University (USA), the University of Southern California (USA), the University of California in San Diego (USA), University of Florida (USA), INSEE (France), CEPII (Prime Minister's Office, France), Chulalongkorn and Thammasat Universities (Thailand), the People's University of China (Beijing) and the National Economics University (Vietnam). Dr Tran Van Hoa has published 18 books and over 100 refereed articles in the major applied and theoretical areas of economics, business, finance, energy and econometrics in Australian and international professional journals, and numerous commissioned reports. He is listed in Who's Who in the World, Who's Who in Asia and the Pacific Nations, Who's Who in Science and Engineering, 2000 Outstanding People of the 20th Century and in the Dictionary of International Biography. He also is a director of T\&M Enterprises P/L (Australia) which provides education and consulting services, and in the past few years he has been a consultant to a number of

organizations and authorities in Australia and China and various ministries in Thailand and Vietnam. 